\title{
Héritage culturel et innovation : les blouses de femmes de la Huastèque (Mexique)
}

\section{Marie-Noëlle Chamoux et Françoise Cousin}

\section{(2) OpenEdition \\ 12 Journals}

Édition électronique

URL : https://journals.openedition.org/tc/823

DOI : $10.4000 /$ tc. 823

ISSN : 1952-420X

Éditeur

Éditions de l'EHESS

\section{Édition imprimée}

Date de publication : 1 octobre 1988

ISSN : 0248-6016

\section{Référence électronique}

Marie-Noëlle Chamoux et Françoise Cousin, « Héritage culturel et innovation : les blouses de femmes de la Huastèque (Mexique) », Techniques \& Culture [En ligne], 11 | 1988, mis en ligne le 16 janvier 2006 consulté le 29 septembre 2022. URL : http://journals.openedition.org/tc/823 ; DOI : https://doi.org/ $10.4000 /$ tc. 823

Ce document a été généré automatiquement le 29 septembre 2022.

Tous droits réservés 
Héritage culturel et innovation : les blouses de femmes de la Huastèque (Mexique)

Marie-Noëlle Chamoux et Françoise Cousin 